\title{
The Effectiveness of Online Based Learning in Universities During the Covid-19 Pandemic
}

\author{
Yari Dwikurnaningsih" ${ }^{1 *}$, Marinu Waruwu ${ }^{2}$ (D) \\ ${ }^{1,2}$ Satya Wacana Christian University, Salatiga, Indonesia
}

\section{A R T I CLE I N F O}

Article history:

Received September 10, 202

Revised September 11, 2021

Accepted October 19, 2021

Available online November 25, 2021

Kata Kunci:

Pembelajaran Online, Pandemi covid19, Kendala, Strategi

Keywords:

Online Learning, Covid-19 Pandemic,

Constraints, Strategy

DOI:

https://dx.doi.org/10.23887/jet.v5i4.353 37

\section{A B S T R A C T}

The Covid-19 pandemic has had an impact on the management of learning in universities. Face-to-face learning has shifted to online-based learning. This study aims to analyze the effectiveness of online-based learning in higher education in terms of aspects of planning, implementation, evaluation, constraints and strategies towards new habits. The research method used quantitative-qualitative descriptive. Data collection techniques used interviews and open-closed questionnaires, the results of which were processed qualitatively by using Miles and Huberman's qualitative data analysis model and quantitative data analysis using mean, categorization and percentage calculations. The population of this study was 1,117 students, while the sample was taken randomly as many as 366 people. Interviews were conducted on 9 lecturers. The results of this study indicate that 1) planning, implementation and evaluation of online based learning get an assessment with a good category, 2) online based learning obstacles can be overcome with a blended learning model strategy, practical courses are carried out face-to-face, choosing materials and courses online, online learning is done through virtual face-to-face, attitude assessment using various instruments, and lecturers giving assignments according to the number of credits for the course. Thus, online based learning in higher education needs to be improved through blended learning models, face-to-face practical courses, attitude assessment instruments with various alternatives, selection of materials and courses online or offline and assignments according to the number of credits.

This is an open access article under the CC BY-SA license. Copyright (C) 2021 by Author. Published by Universitas Pendidikan Ganesha.

\begin{abstract}
Pandemi Covid 19 memiliki dampak pada pengelolaan pembelajaran di perguruan tinggi. Pembelajaran yang dilakukan secara tatap muka beralih ke elajaran berbasis online. Penelitian ini bertujuan untuk menganal aspek perencanaan, pelaksanaan, evaluasi, kendala dan strategi menuju kebiasaan baru. Metode penelitian menggunakan deskriptif kuantitatifkualitatif. Teknik pengumpulan data menggunakan wawancara dan angket data menggunakan penghitungan rerata, pengkategorian dan prosentase. Populasi penelitian ini adalah, 1.117 mahasiswa, sedangkan sampel diambil secara random sebanyak 366 orang. Wawancara dilakukan terhadap 9 dosen. Hasil pada pembelajaran berbasis online mendapatkan, pelaksanaan dan evaluasi baik, 2) kendala pembelajaran berbasis online dapat diatasi dengan strategi model blended learning, mata kuliah praktik dilakukan secara tatap muka, memilih materi dan mata kuliah daring-luring, pembelajaran daring dilakukan
melalui tatap muka virtual, penilaian sikap dengan menggunakan berbagai instrumen, dan dosen memberikan tugas sesuai besaran SKS mata kuliah. ditingkatkan melalui pembelajaran berbasis online di perguruan tinggi perlu muka, intrumen penilaian sikap dengan berbagai alternatif, pemilihan materi dan mata kuliah secara daring atau luring dan pemberian tugas sesuai besaran SKS.
\end{abstract}


Learning that was previously face-to-face has shifted to learning from home by utilizing online facilities. Because learning is done from home, universities use various information technology tools to support the ongoing learning process with students. Online-based learning in higher education can connect students with their learning resources, communicate reciprocally and collaborate synchronously and asynchronously (Sadikin \& Hamidah, 2020). The Faculty of Teacher Training and Education, Satya Wacana Christian University since the beginning of 2020 has been organizing online-based learning. This policy aims to support government policies related to the implementation of online-based learning. Online-based learning is learning that is carried out remotely using various information technology applications, internet networks with accessibility, connectivity, flexibility, and the ability to bring up various types of learning interactions (Hoi et al., 2021; Lemay et al., 2021; Mulyono et al., 2021; Sadikin \& Hamidah, 2020). Information and communication technology facilities used in online lectures at universities are learning management systems or flexible learning, zoom meetings, gmeet, google classroom, whatsapp, email, youtube, tactics (Maqableh \& Alia, 2021; Saha et al., 2021). The use of various technology applications is adjusted to the needs of lecture content delivered by lecturers to students. For example, interactions at gmeet and zoom meetings are aimed at explaining material, and the learning management system is used for filling out attendance lists, collecting assignments, discussing, and so on.

On the other hand, online-based learning in universities has its drawbacks. Based on a preliminary study conducted by researchers, online-based learning has limitations, including: lack of readiness of lecturers and students to operate various learning technology applications, limited network access in remote areas, limited funds for internet facilities such as fulfilling quotas for economically disadvantaged students, psychological problems, communication interactions between lecturers and students are decreasing, discussions in the learning management system are felt to be less effective, instruction is limited (Albashtawi \& Al Bataineh, 2020; Ferri et al., 2020; J. Li et al., 2018). These results are in line with the findings of Abroto et al., that the application of online learning is constrained by the internet network, not all have technological devices, lack of supervision, limited student funds (Abroto Andi; Anantama, Raka, 2021). These obstacles require solutions from related parties to overcome them, such as policy makers, universities, lecturers, students and parents. Problems are overcome by the principles of collaboration and synergy.

Based on previous research, online-based learning in universities is very effective. The results of research by Satyawan et al., that online-based learning using Undiksha's E-Learning during the covid-19 pandemic in the Physical Education and Health Study program is considered effective which has implications for the sustainability of Undiksha's use of e-learning as a learning platform used by lecturers and students (Amin et al., 2021; Nácher et al., 2021; Satyawan et al., 2021). Online system-based lectures have a positive and significant effect on learning satisfaction and increase learning enthusiasm and seriousness. The weblog-based online learning has a positive effect on improving students' English reading skills (Khusniyah \& Hakim, 2019). The three results of this study show the effectiveness of online-based learning. The success of the implementation is largely determined by the readiness of teaching staff and students, facilities, network access, and the availability of resources for smooth learning. The gap that occurs between the results of previous research and the results of preliminary research studies shows that there are problems in online-based learning in universities. The success of the implementation of online-based learning is largely determined by the availability of hardware and software facilities, the availability of internet networks, the readiness of teaching staff, and digitized materials (Binali et al., 2021; Glassman et al., 2021; Rahma \& Pujiastuti, 2021; Selvaraj et al., 2021; Tang et al., 2021). This study aims to analyze the effectiveness of online-based learning in universities during the Covid 19 pandemic. The effectiveness of online-based learning success is measured from aspects of planning, implementation, evaluation, obstacles that occur and future learning strategies. The results of this study are expected to be useful for improving online-based learning services in higher education in the future.

\section{METHOD}

This research is a survey research with a qualitative-quantitative approach or a mix method. Qualitative approach was conducted to obtain information through interviews. A quantitative approach to analyze the effectiveness of online-based learning obtained through the distribution of questionnaires. A qualitativequantitative approach (mix method) was carried out to complement and strengthen the research results found in the field. The population of this study were students of the Satya Wacana Christian University as many as 1,177 students. The sample of this study was 366 students or $31 \%$ of the total population taken by random sampling. Data collection techniques used a questionnaire with closed and open questions, and interviews. Questionnaires are a number of questions or written statements about factual data or opinions relating to the respondent. The questionnaire in this study was a list of written questions in the form of the level of student and lecturer satisfaction on the effectiveness of online-based learning in higher education. The questionnaire aims to get feedback from students and lecturers about the effectiveness of online-based learning. The instrument used is a 
closed and open questionnaire. The closed questionnaire instrument uses a Likert scale of 4 which is categorized from 1 to 4 which is described as "Not Good", "Poor", "Good", and "Very Good" (Sumardi et al., 2021; Tanti et al., 2021).

Questionnaires were distributed to 366 students via google form. Aspects measured include 1) planning aspects including learning implementation plans (RPS), readiness of learning platforms (learning management system), development of teaching materials and learning resources, media development, and preparing evaluation tools, 2) implementation aspects including platforms/applications used, interaction between lecturers and students, existing facilities in the learning management system, use of media to facilitate mastery of materials, easily accessible teaching materials, and assessment of assignments and tests, 3) evaluation aspects include knowledge, skills, practices, and attitudes. The interview method in this study aims to find out in-depth information about implementation constraints and online-based learning strategies. The aspects interviewed are the availability of facilities, the availability of internet quota, and internet network. Researchers conducted interviews with students and lecturers. The observations were made on the implementation of online-based learning in higher education. In more detail, the research instrument can be seen in table 1 below.

Table 1. Online-Based Learning Instruments in Higher Education

\begin{tabular}{|c|c|c|}
\hline No & Aspect & Indicator \\
\hline \multirow[t]{6}{*}{1} & Online Learning & 1. Semester lesson plan \\
\hline & Planning & 2. Instrument/platform readiness \\
\hline & & 3. Development of teaching materials \\
\hline & & 4. Media development \\
\hline & & 5. Development of evaluation tools \\
\hline & & 6. The suitability of the load of the tasks assigned to the credit load \\
\hline \multirow[t]{8}{*}{2} & Implementation of & 1. Implementation of learning aspects of knowledge \\
\hline & Online Learning & 2. Implementation of learning aspects of skills \\
\hline & & 3. Implementation of learning aspects of attitude \\
\hline & & 4. The learning method used \\
\hline & & 5. The learning media used \\
\hline & & 6. Ease of use of the platform \\
\hline & & 7. Lecturer skills in using information and communication technology \\
\hline & & 8. Motivation in online learning \\
\hline \multirow[t]{5}{*}{3} & Evaluation of Online & 1. The suitability of the evaluation instrument with the course credit load \\
\hline & Learning & 2. Evaluation measures aspects of knowledge \\
\hline & & 3. Evaluation measures aspects of attitude \\
\hline & & 4. Evaluation measures aspects of skills \\
\hline & & 5. Conformity of the evaluation form with the assessed aspects \\
\hline \multirow[t]{6}{*}{4} & Constraints of Online & 1. Ability to use information and communication technology \\
\hline & Learning & 2. Availability of infrastructure \\
\hline & & 3. Internet network \\
\hline & & 4. Mastery of theoretical and practical material \\
\hline & & 5. Location \\
\hline & & 6. Finance to buy credit \\
\hline \multirow[t]{3}{*}{5} & Ideal Learning Models & 1. Blended Learning \\
\hline & during a Pandemic & 2. Fully Online \\
\hline & & 3. Full Face to face learning \\
\hline
\end{tabular}

Data analysis techniques used quantitative descriptive analysis techniques by calculating averages and percentages, and qualitative data analysis techniques with the model proposed by Miles and Huberman include: (1) data condensation, (2) data presentation, and (3) retrieval and verification conclusions (Hapsari \& Fitria, 2020).

\section{RESULT AND DISCUSSION}

\section{Result}

The success of online-based learning planning in higher education is measured by indicators of a learning implementation plan (RPS), preparation of a learning platform or learning management system, development of teaching materials and learning resources, development of media, and preparation of learning evaluation tools. Based on research data, online-based learning planning conducted by lecturers shows that 
$51.88 \%$ (190 students) stated very well, 46, 24\% (169 students) stated good, 1.50\% (5 students) stated not good, and only $0.38 \%$ (1 student) said it was not good. The success of the implementation of online-based learning is measured based on indicators of platform/application management, interaction between lecturers and students, ease of access to existing facilities in the learning management system, use of media to facilitate mastery of materials, easily accessible teaching materials, and assessment of assignments and tests. The results of the survey on the implementation of online-based learning in universities showed 39.47\% (144 students) rated very good, $59.40 \%$ (217 students) rated it good, and $1.13 \%$ (4 students) rated it not good, and the rest is not there. The success of the evaluation of online-based learning is measured based on indicators of the level of achievement of knowledge, skills, practices, and attitudes. The results of the survey on the implementation of evaluation of learning outcomes during online-based learning in universities showed 39.86\% (146 students) rated very good, $54.89 \%$ (201 students) rated good, 3.01\% (11 students) rated less good, and 2.24\% (8 students) rated it not good.

In addition, researchers obtained evaluation data on the skills aspect showing that $76.65 \%(281$ students) were less satisfied, and $23.35 \%$ (85 students) were satisfied. It can also be seen from the students' opinions that the implementation of practical online learning, such as microteaching, internships, practicums shows that $83.46 \%$ (307 students) are not satisfied and only 16.54\% (61 students) are satisfied. The attitude assessment is carried out through attendance which can be done through learning management systems and academic information systems, activeness in discussions, accuracy of task collection, and ways of communicating both verbally through virtual face-to-face and in writing in discussions and chats on LMS and through WA groups. Researchers obtained factual data in the field that during the pandemic, 56.71\% (208 students) chose blended learning, $21.52 \%$ (79 students) chose fully online-based learning, and $21.77 \%$ (80 students) students) choose full face-to-face learning. In the implementation of online learning so far, most lecturers use the learning management system that has been provided (flexible learning), but there are lecturers who use Google Classroom and Schoology. Students prefer to have synchronous meetings through virtual faceto-face activities, because they can communicate directly with lecturers and fellow students. The results of the survey of student perceptions about the ideal learning model with blended learning, full online learning, and full face-to-face learning. The qualitative data obtained by the researcher shows that the obstacles in implementing online-based learning in universities are the availability of facilities used by students, the availability of student internet quotas, and the internet network which is sometimes not good so that communication is not smooth, assignments pile up, deadlines for collecting assignments, communication less fluent, students are less free to choose where to practice microteaching. The learning can be done anytime and anywhere. Lecturers are expected to be skilled in the management of learning facilities.

\section{Discussion}

Based on the results of the study, online-based learning planning in universities as a whole received student responses at the level of the good category. Semester lesson plans (RPS) were developed in accordance with the demands of online-based learning. Preparation is done by creating a mapping program that contains learning object materials, namely learning materials that will be used and uploaded in the learning management system, whether in the form of text, images, photos, audio, video, and the type of assessment used. Interaction forms and facilities are in the form of chat, discussion forums, through virtual face-to-face with zoom facilities, google meet or other applications, and improvement of facility operation skills (Hardie et al., 2021; Lemay et al., 2021; Muflih et al., 2021; Wong et al., 2021). Learning resources that will be used are prepared so that students can access and use them in learning. It is necessary to allocate time for these activities, so that they can be well planned. Learning objects make it possible to be used for the development of creative and innovative learning (Kusnandar, 2014; Suryawati \& Osman, 2018). The implementation of online-based learning gets an assessment in a good category, there is interaction in learning, virtual face-to-face activities are carried out and use learning media. Students have a positive perception of online learning, both in terms of implementation and the capability of the lecturers (Eze et al., 2018; Saragih et al., 2020). The same thing was also found in the results that online learning is quite effective and efficient to replace face-to-face lectures (Widayati, 2020; Yulia, 2020). Online learning can increase enthusiasm and responsibility in doing assignments on time.

First, online learning or blended learning, it is necessary to sort and select courses and materials that will be carried out offline and online. Theoretical courses and materials can be conducted online, while practical courses and materials are carried out offline (Choi et al., 2021; Grønlien et al., 2021; Lapitan et al., 2021; Mali \& Lim, 2021; Meulenbroeks, 2020; Prahmana et al., 2021). Second, designing lectures using a learning management system and virtual face-to-face activities. Learning materials are developed with various sources and types that can be accessed by students online, both through the learning management system and outside the learning management system such as youtube, journals, proceedings, e-books, and scientific articles. Learning media are well prepared to support virtual face-to-face learning such as power point materials, pawtoons, and videos (Lwande et al., 2021; Lyashenko \& Malinina, 2015; Mehrolia et al., 2021; Nguyen, 2021). Third, optimizing facilities in the learning management system by uploading lecture materials and media, assignments, 
quizzes, chats, discussion forums, and evaluations. The use of virtual face-to-face applications, such as zoom and google meet, can complement the activities in the LMS. Through virtual face-to-face interaction can occur synchronously so that if there are things that are not clear, they can be directly asked/discussed. Group discussions through virtual face-to-face can use breakout room facilities, so they can discuss in their respective groups then return to the main room for class discussion (Aldiab et al., 2019; Bezverhny et al., 2020; Brenner \& Hummel, 2017; Pavlenko et al., 2020).

Fourth, the implementation of internships, several strategies are needed that can be carried out by the Education Personnel Education Institution (LPTK) so that students can gain experience from internship activities. The LPTK can identify the student's school and place of residence, so that it can place students in the school closest to their place of residence. This will make it easier for students to adjust to the socio-cultural conditions of the school and its environment. The LPTKs in guiding students and communicating with schools can be done face-to-face. Reports of activities in stages as well as discussions of obstacles and how to overcome them can use the facilities in the LMS. Related to this internship activity, students need to be equipped with the ability to use learning platforms, strategies, models, media, evaluation of online learning and increase student creativity in providing teaching materials. Thus, when students are placed in schools that have implemented online learning, they can practice and help teachers develop and implement online learning (Gohae, 2020; Samidjo, 2017; Setyorini et al., 2017; Suharyanti et al., 2015). This study has limitations, they are that the sample only comes from students at the Satya Wacana Christian University, Salatiga, Central Java. It is expected that in the future the research sample needs to be expanded by involving other students from various universities in Central Java so that the results are more varied and have diverse perspectives. Thereforem to improve the effectiveness of online-based learning, universities need to apply a blended learning-based learning model, practical courses are carried out face-to-face, select materials and courses online, online learning is carried out through virtual face-to-face, attitude assessment using various instruments, and the lecturer gives assignments according to the number of credits of the course. Thus, online-based learning is expected to be effective in improving the quality of learning in higher education.

\section{CONCLUSION}

The effectiveness of online-based learning in higher education in terms of planning, implementation and evaluation aspects gets an assessment in a good category. Constraints of online-based learning can be overcome by applying a blended learning-based learning model strategy, practical courses are conducted face-to-face, choosing online-offline materials and courses, online learning is carried out through virtual face-to-face, attitude assessment using various instruments, and lecturers provide assignments according to the size of the course credits. This study has limitations because the results obtained are only for the context of the Satya Wacana Christian University.

\section{REFERENCES}

Abroto Andi; Anantama, Raka, A. P. (2021). Analisis Hambatan Proses Pembelajaran Daring dengan Menggunakan Aplikasi Whatsapp di Sekolah Dasar. Jurnal Basicedu, 5(Vol 5, No 3 (2021): June Pages 1111-1682), 1632-1638. https://doi.org/10.31004/basicedu.v5i3.971.

Abumalloh, R. A., Asadi, S., Nilashi, M., Minaei-Bidgoli, B., Nayer, F. K., Samad, S., Mohd, S., \& Ibrahim, O. (2021). The impact of coronavirus pandemic (COVID-19) on education: The role of virtual and remote laboratories in education. Technology in Society, 67(September 2020), 101728. https://doi.org/10.1016/j.techsoc.2021.101728.

Albashtawi, A. H., \& Al Bataineh, K. B. (2020). The effectiveness of google classroom among EFL students in Jordan: An innovative teaching and learning online platform. International Journal of Emerging Technologies in Learning, 15(11), 78-88. https://doi.org/10.3991/IJET.V15I11.12865.

Aldiab, A., Chowdhury, H., Kootsookos, A., Alam, F., \& Allhibi, H. (2019). Utilization of Learning Management Systems (LMSs) in higher education system: A case review for Saudi Arabia. Energy Procedia, 160(2018), 731-737. https://doi.org/10.1016/j.egypro.2019.02.186.

Amin, I., Yousaf, A., Walia, S., \& Bashir, M. (2021). What Shapes E-Learning Effectiveness among Tourism Education Students? An Empirical Assessment during COVID19. Journal of Hospitality, Leisure, Sport and Tourism Education, xxx(xxxx), 100337. https://doi.org/10.1016/j.jhlste.2021.100337.

Bezverhny, E., Dadteev, K., Barykin, L., Nemeshaev, S., \& Klimov, V. (2020). Use of chat bots in Learning Management Systems. Procedia Computer Science, 169(2019), 652-655. https://doi.org/10.1016/j.procs.2020.02.195.

Binali, T., Tsai, C. C., \& Chang, H. Y. (2021). University students' profiles of online learning and their relation to online metacognitive regulation and internet-specific epistemic justification. Computers and 
Education, 175(August), 104315. https://doi.org/10.1016/j.compedu.2021.104315.

Brenner, B., \& Hummel, V. (2017). Digital Twin as Enabler for an Innovative Digital Shopfloor Management System in the ESB Logistics Learning Factory at Reutlingen - University. Procedia Manufacturing, 9, 198-205. https://doi.org/10.1016/j.promfg.2017.04.039.

Choi, J. J., Robb, C. A., Mifli, M., \& Zainuddin, Z. (2021). University students' perception to online class delivery methods during the COVID-19 pandemic: A focus on hospitality education in Korea and Malaysia. Journal of Hospitality, Leisure, Sport and Tourism Education, 29(August), 100336. https://doi.org/10.1016/j.jhlste.2021.100336.

Dhanalakshmi, R., Anuja Mary, A., Shrijith, D., \& Vijayaraghavan, N. (2021). A study on Covid-19 - Impacting Indian education. Materials Today: Proceedings, xxxx. https://doi.org/10.1016/j.matpr.2021.02.786.

Eze, S. C., Chinedu-Eze, V. C., \& Bello, A. O. (2018). The utilisation of e-learning facilities in the educational delivery system of Nigeria: a study of M-University. International Journal of Educational Technology in Higher Education, 15(1). https://doi.org/10.1186/s41239-018-0116-z.

Ferri, F., Grifoni, P., \& Guzzo, T. (2020). Online Learning and Emergency Remote Teaching: Opportunities and Challenges in Emergency Situations. Societies, 10(4), 86. https://doi.org/10.3390/soc10040086.

Glassman, M., Kuznetcova, I., Peri, J., \& Kim, Y. (2021). Cohesion, collaboration and the struggle of creating online learning communities: Development and validation of an online collective efficacy scale. Computers and Education Open, 2(January), 100031. https://doi.org/10.1016/j.caeo.2021.100031.

Gohae, A. S. (2020). Pengalaman Magang, Minat Kerja Dan Pengaruhnya Terhadap Kesiapan Kerja Mahasiswa Akuntansi. Jurnal Ilmiah MEA, 4(3), 1954-1964. https://doi.org/10.31955/mea.vol4.iss3.pp1954-1964.

Grønlien, H. K., Christoffersen, T. E., Ringstad, Ø., Andreassen, M., \& Lugo, R. G. (2021). A blended learning teaching strategy strengthens the nursing students' performance and self-reported learning outcome achievement in an anatomy, physiology and biochemistry course - A quasi-experimental study. Nurse Education in Practice, 52(June 2020). https://doi.org/10.1016/j.nepr.2021.103046.

Hapsari, T. P. R. N., \& Fitria, A. S. (2020). Efektivitas Pembelajaran Daring Mata Kuliah Evaluasi Pengajaran Bahasa Dan Sastra Indonesia Masa Pandemi Covid-19. Jurnal Ilmiah SEMANTIKA, 2(01), 11-20. https://doi.org/10.46772/semantika.v2i01.259.

Hardie, P., Donnelly, P., Greene, E., McHugh, A., Coveney, K., Murray, B., \& Brereton, S. (2021). The application of reusable learning objects (RLOs) in preparation for a simulation laboratory in medication management: An evaluative study. Teaching and Learning in Nursing, 16(4), 301-308. https://doi.org/10.1016/j.teln.2021.05.002.

Herdiana, D., Rudiana, R., \& Supriatna, S. (2021). Kejenuhan Mahasiswa dalam Mengikuti Perkuliahan Daring dan Strategi Penanggulangannya. Edunesia: Jurnal Ilmiah Pendidikan, 2(1), 293-307. https://doi.org/10.51276/edu.v2i1.128.

Hoi, S. C. H., Sahoo, D., Lu, J., \& Zhao, P. (2021). Online learning: A comprehensive survey. Neurocomputing, 459, 249-289. https://doi.org/10.1016/j.neucom.2021.04.112.

Hyman, M., Mark, C., Imteaj, A., Ghiaie, H., Rezapour, S., Sadri, A. M., \& Amini, M. H. (2021). Data analytics to evaluate the impact of infectious disease on economy: Case study of COVID-19 pandemic. Patterns, 2(8), 100315. https://doi.org/10.1016/j.patter.2021.100315.

Khusniyah, N. L., \& Hakim, L. (2019). Efektivitas Pembelajaran Berbasis Daring: Sebuah Bukti Pada Pembelajaran Bahasa Inggris. Jurnal Tatsqif, 17(1), 19-33. https://doi.org/10.20414/jtq.v17i1.667.

Kusnandar, K. (2014). Pengembangan Bahan Belajar Digital Learning Object. Jurnal Teknodik, 17(1), 583-595. https://doi.org/10.32550/teknodik.v0i0.69.

Lapitan, L. D., Tiangco, C. E., Sumalinog, D. A. G., Sabarillo, N. S., \& Diaz, J. M. (2021). An effective blended online teaching and learning strategy during the COVID-19 pandemic. Education for Chemical Engineers, 35(May 2020), 116-131. https://doi.org/10.1016/j.ece.2021.01.012.

Lemay, D. J., Bazelais, P., \& Doleck, T. (2021). Transition to online learning during the COVID-19 pandemic. Computers in Human Behavior Reports, 4, 100130. https://doi.org/10.1016/j.chbr.2021.100130.

Li, J., Zhang, X., \& Hu, Z. (2018). The design and application of flip classroom teaching based on computer technology. International Journal of Emerging Technologies in Learning, 13(10), 95-107. https://doi.org/10.3991/ijet.v13i10.9453.

Li, Y., Zhuang, X., Wang, J., \& Dong, Z. (2021). Analysis of the impact of COVID-19 pandemic on G20 stock markets. North American Journal of Economics and Finance, 58(January), 101530. https://doi.org/10.1016/j.najef.2021.101530.

Lwande, C., Muchemi, L., \& Oboko, R. (2021). Identifying learning styles and cognitive traits in a learning management system. Heliyon, 7(8). https://doi.org/10.1016/j.heliyon.2021.e07701.

Lyashenko, M. S., \& Malinina, I. A. (2015). The Use of Learning Management System Projects for Teaching a Foreign Language in the University. Procedia - Social and Behavioral Sciences, 182, 81-88. https://doi.org/10.1016/j.sbspro.2015.04.741. 
Mali, D., \& Lim, H. (2021). How do students perceive face-to-face/blended learning as a result of the Covid-19 pandemic? International Journal of Management Education, 19(3), 100552. https://doi.org/10.1016/j.ijme.2021.100552.

Maqableh, M., \& Alia, M. (2021). Evaluation online learning of undergraduate students under lockdown amidst COVID-19 Pandemic: The online learning experience and students' satisfaction. Children and Youth Services Review, 128, 106160. https://doi.org/10.1016/j.childyouth.2021.106160.

Mehrolia, S., Alagarsamy, S., \& Indhu Sabari, M. (2021). Moderating effects of academic involvement in webbased learning management system success: A multigroup analysis. Heliyon, 7(5), e07000. https://doi.org/10.1016/j.heliyon.2021.e07000.

Meulenbroeks, R. (2020). Suddenly fully online: A case study of a blended university course moving online during the Covid-19 pandemic. Heliyon, 6(12), e05728. https://doi.org/10.1016/j.heliyon.2020.e05728.

Muflih, S., Abuhammad, S., Al-Azzam, S., Alzoubi, K. H., Muflih, M., \& Karasneh, R. (2021). Online learning for undergraduate health professional education during COVID-19: Jordanian medical students' attitudes and perceptions. Heliyon, 7(9), e08031. https://doi.org/10.1016/j.heliyon.2021.e08031.

Mulyono, H., Suryoputro, G., \& Jamil, S. R. (2021). The application of WhatsApp to support online learning during the COVID-19 pandemic in Indonesia. Heliyon, 7(8), e07853. https://doi.org/10.1016/j.heliyon.2021.e07853.

Nácher, M. J., Badenes-Ribera, L., Torrijos, C., Ballesteros, M. A., \& Cebadera, E. (2021). The effectiveness of the GoKoan e-learning platform in improving university students' academic performance. Studies in Educational Evaluation, 70. https://doi.org/10.1016/j.stueduc.2021.101026.

Nguyen, N. T. (2021). A study on satisfaction of users towards learning management system at International University - Vietnam National University HCMC. Asia Pacific Management Review, xxxx, 1-11. https://doi.org/10.1016/j.apmrv.2021.02.001

Noori, A. Q. (2021). The Impact of COVID-19 Pandemic on Students' Learning in Higher Education in Afghanistan. Heliyon, 7(June), e08113. https://doi.org/10.1016/j.heliyon.2021.e08113.

Pal, K. B., Basnet, B. B., Pant, R. R., Bishwakarma, K., Kafle, K., Dhami, N., Sharma, M. L., Thapa, L. B., Bhattarai, B., \& Bhatta, Y. R. (2021). Education system of Nepal: impacts and future perspectives of COVID-19 pandemic. Heliyon, 7(9), e08014. https://doi.org/10.1016/j.heliyon.2021.e08014.

Pavlenko, D., Barykin, L., Nemeshaev, S., \& Bezverhny, E. (2020). Individual approach to knowledge control in learning management system. Procedia Computer Science, 169(2019), 259-263. https://doi.org/10.1016/j.procs.2020.02.162.

Prahmana, R. C. I., Hartanto, D., Kusumaningtyas, D. A., Ali, R. M., \& Muchlas. (2021). Community radiobased blended learning model: A promising learning model in remote area during pandemic era. Heliyon, 7(7), e07511. https://doi.org/10.1016/j.heliyon.2021.e07511.

Rahma, N. A., \& Pujiastuti, H. (2021). Efektivitas Pembelajaran Daring Matematika Pada Masa Pandemi Covid19 Di Kota Cilegon [the Effectiveness of Mathematics Online Learning During the Covid-19 Pandemic in Cilegon City]. JOHME: Journal of Holistic Mathematics Education, 5(1), 1. https://doi.org/10.19166/johme.v5i1.3811.

Sadikin, A., \& Hamidah, A. (2020). Pembelajaran Daring di Tengah Wabah Covid-19. Biodik, 6(2), $109-119$. https://doi.org/10.22437/bio.v6i2.9759.

Saha, A., Dutta, A., \& Sifat, R. I. (2021). The mental impact of digital divide due to COVID-19 pandemic induced emergency online learning at undergraduate level: Evidence from undergraduate students from Dhaka City. Journal of Affective Disorders, 294(June), 170-179. https://doi.org/10.1016/j.jad.2021.07.045.

Samidjo, S. (2017). Efektifitas Pelaksanaan Magang Industri Mahasiswa Program Studi Pendidikan Teknik Mesin. Taman Vokasi, 2(2), 246. https://doi.org/10.30738/jtvok.v5i2.2528.

Saragih, O., Sebayang, F. A. A., Sinaga, A. B., \& Ridlo, M. R. (2020). Kepuasaan Mahasiswa terhadap Pembelajaran Daring Selama Pandemi Covid-19. Journal of Language and Health, 7(3), 49-56. https://doi.org/10.37287/jlh.v1i2.383.

Satyawan, I. M., Wahjoedi, W., \& Swadesi, I. K. I. (2021). The Effectiveness of Online Learning Through Undiksha E-Learning During the Covid-19 Pandemic. Journal Education Technology, 5(2). https://doi.org/10.23887/jet.v5i2.32364

Selvaraj, A., Radhin, V., KA, N., Benson, N., \& Mathew, A. J. (2021). Effect of pandemic based online education on teaching and learning system. International Journal of Educational Development, 85(May), 102444. https://doi.org/10.1016/j.ijedudev.2021.102444.

Setyorini, D., Lestari, B., Purwanto, P., Winarno, W., \& Sagoro, E. M. (2017). Model Magang Industri Guna Pencapaian Standar Kompetensi Lulusan Fakultas Ekonomi Universitas Negeri Yogyakarta. Jurnal Pendidikan Akuntansi Indonesia, 14(2), 37-47. https://doi.org/10.21831/jpai.v14i2.12868.

Srifuengfung, M., Thana-udom, K., Ratta-apha, W., Chulakadabba, S., Sanguanpanich, N., \& Viravan, N. 
(2021). Impact of the COVID-19 pandemic on older adults living in long-term care centers in Thailand, and risk factors for post-traumatic stress, depression, and anxiety. Journal of Affective Disorders, 295(August), 353-365. https://doi.org/10.1016/j.jad.2021.08.044.

Suharyanti, C., Murtini, W., \& Susilowati, T. (2015). Pengaruh Proses Pembelajaran dan Program Kerja Praktek Terhadap Pengembangan Soft Skill Mahasiswa. Jurnal Pendidikan Administrasi Perkantoran, 4(1), 18.

Sumardi, D., Suryani, N., \& Musadad, A. A. (2021). Website-Based Learning Management System (LMS) as a Tool for Learning in the Covid-19 Pandemic Period for Junior High Schools. Journal of Education Technology, 5(3), 346. https://doi.org/10.23887/jet.v5i3.38371.

Suryawati, E., \& Osman, K. (2018). Contextual learning: Innovative approach towards the development of students' scientific attitude and natural science performance. Eurasia Journal of Mathematics, Science and Technology Education, 14(1), 61-76. https://doi.org/10.12973/ejmste/79329.

Tang, Y. M., Chen, P. C., Law, K. M. Y., Wu, C. H., Lau, Y., Guan, J., He, D., \& Ho, G. T. S. (2021). Comparative analysis of Student's live online learning readiness during the coronavirus (COVID-19) pandemic in the higher education sector. Computers \& Education, 168, 104211. https://doi.org/10.1016/j.compedu.2021.104211.

Tanti, T., Darmaji, D., Astalini, A., Kurniawan, D. A., \& Iqbal, M. (2021). Analysis of User Responses to the Application of Web-Based Assessment on Character Assessment. Journal of Education Technology, 5(3), 356. https://doi.org/10.23887/jet.v5i3.33590.

Vera, N. (2020). Strategi Komunikasi Dosen Dan Mahasiswa Dalam Meningkatkan Kualitas Pembelajaran Daring Selama Pandemic Covid-19. Avant Garde, 8(2), 165. https://doi.org/10.36080/ag.v8i2.1134.

Widayati, S. (2020). Respon Mahasiswa Pada Mata Kuliah Daring. Child Education Journal, 2(1), 48-52. https://doi.org/10.33086/cej.v2i1.1506.

Wong, J., Baars, M., He, M., de Koning, B. B., \& Paas, F. (2021). Facilitating goal setting and planning to enhance online self-regulation of learning. Computers in Human Behavior, 124(June). https://doi.org/10.1016/j.chb.2021.106913.

Yulia, H. (2020). Online Learning to Prevent the Spread of Pandemic Corona Virus in Indonesia. ETERNAL (English Teaching Journal), 11(1). https://doi.org/10.26877/eternal.v11i1.6068.

Zhou, Y., Feng, L., Zhang, X., Wang, Y., Wang, S., \& Wu, T. (2021). Spatiotemporal patterns of the COVID-19 control measures impact on industrial production in Wuhan using time-series earth observation data. Sustainable Cities and Society, August, 103388. https://doi.org/10.1016/j.scs.2021.103388. 